\begin{tabular}{|c|c|c|}
\hline \multirow[t]{3}{*}{ BENTHAM OPEN } & Pharmaceutical Crops & Pharmaceutical Crops \\
\hline & Content list available at: www.benthamopen.com/TOPHARMCJ/ & \\
\hline & DOI: $10.2174 / 2210290601606010013$ & \\
\hline
\end{tabular}

RESEARCH ARTICLE

\title{
Assessment of Chemopreventive Contents of Native American Juneberries (Amelanchier alnifolia (Nutt.) Nutt. ex M. Roem.)
}

\author{
Shimara Gunawardana ${ }^{1}$, Keeli Eberhart ${ }^{1}$, Kerry Hartman ${ }^{2}$ and Fathi T. Halaweish ${ }^{1, *}$ \\ ${ }^{1}$ Department of Chemistry \& Biochemistry, South Dakota State University, Box 2202, Brookings, SD 57007, USA \\ ${ }^{2}$ Nueta Hidatsa Sahnish College, PO Box 490, New Town, ND 58763
}

\begin{abstract}
Juneberry (Amelanchier alnifolia) is a shrub with edible berry-like fruit commonly found across the Northern Great Plains of North America and widely used by Native Americans as a medicinal plant. This study was an effort to assess the chemopreventive contents of juneberry extracts in ethanol by measuring the total phenolic content, orthophenolic content, DPPH radical scavenging activity, ABTS radical cation decolorization assay, and cytoprotective effects on HepG2 cells. The total phenolic content upon treatment with Folin-Ciocalteu's reagent ranged from $0.2261 \pm 0.0031$ to $19.311 \pm 1.651 \mathrm{mg} . \mathrm{g}^{-1}$ tannic acid equivalents. Orthophenolic content quantified by monitoring the bathochromic shifts upon reacting with sodium molybdate ranged from $0.12 \pm$ 0.03 to $2.38 \pm 0.15 \mathrm{mg} \cdot \mathrm{g}^{-1}$ of FW. Antioxidant activity using DPPH assay ranged from $50.08 \pm 0.77$ to $98.60 \pm 1.12 \%$, in contrast to quercetin dihydrate with an activity of $86.20 \pm 0.05 \%$. ABTS radical scavenging assay produced inhibition from $1.90 \pm 0.11$ to 60.25 $\pm 1.65 \%$ as opposed to 6-hydroxy-2, 5, 7, 8-tetramethylchroman-2-carboxylic acid (Trolox) with an inhibition of $94.03 \pm 0.21 \%$. HepG2 cells treated with $100 \mu \mathrm{g} / \mu \mathrm{L}$ of sample WC2B showed $56 \%$ cell-viability against tert-Butyl hydroperoxide in comparison to quercetin dihydrate which showed $90 \%$ cytoprotection. Total phenolic content and orthophenolic content in juneberries from 2012 were higher than in juneberries obtained from the 2013 and 2014. Similarly fruit grown in the wild showed significantly higher antioxidant activity and phenolic content than those grown in domestic cultivars.
\end{abstract}

Keywords: Juneberry, Amelanchier alnifolia, Chemopreventive, Antioxidant activity, Native American, Cytoprotection, phenolics, DPPH, ABTS, Orthophenolic, TBHP.

\section{INTRODUCTION}

Human cells are repeatedly exposed to free radicals, species with unpaired electrons some of which are vital for physiological function. However, an uncontrolled exposure of cells to oxidants gives rise to oxidative stress which could be harmful to biomolecules. By-products of aerobic respiration, phagocytic cells, peroxisomes, and cytochrome P450 enzymes are found to be responsible for degenerative diseases such as cancer, cardiovascular disease, immunesystem decline, brain dysfunction, cataract, and overall aging [1]. Dietary antioxidants quench reactive oxygen species (ROS) and reactive nitrogen species (RNS) to either halt radical chain reactions or prevent the formation of further ROS/RNS. Antioxidants consumed by food are mainly radical chain reaction inhibitors, metal chelators, oxidative enzymes inhibitors and antioxidant enzyme cofactors [2]. Many studies have shown an inverse relationship between dietary antioxidant flavonoid intake such as black tea, onions, apples, and risk of coronary heart disease and prostate cancer $[3,4]$. The majority of the renowned natural compounds having chemotherapeutic effects against cancer are phytochemicals, and these are further categorized into phenolic compounds, alkaloids, lectins, terpenoids, isoprenoids, and quinones [5]. These components could individually or collectively display chemotherapeutic effects by a mechanism known as antioxidant activity [6].

\footnotetext{
"Address correspondence to this author at the Department of Chemistry \& Biochemistry, South Dakota State University, Box 2202, Brookings, SD 57007, USA; E-mail: Fathi.halaweish@sdstate.edu
} 
Amelanchier alnifolia (Nutt.) Nutt. . ex M. Roem. (Rosaceae) is a shrub native to the Northern Great Plains of North America. Although commonly referred to as juneberry, it has a veritable book of aliases such as serviceberry, saskatoon berry, and shadbush. Native Americans are known for the extensive use of juneberries as a source of food and medicine. Historically, fruits were consumed both fresh, dried and mixed with meat, while native tribes also used tea made of juneberry branches to recover from colds, bark to relieve stomach problems, and twigs to gain strength following childbirth [7].

A Finnish study profiling the phytochemicals in A. alnifolia plant, leaves, stems, and berries using HPLC-DAD and LPLC-ESI/MS reported that the berry portion was majorly comprised of cyanidin-based anthocyanins, hydroxycinnamic acid, and quercetin-derived flavonol glycosides, while the stem portion was comprised of flavanone, flavonol glycosides, catechins, and hydroxybenzoic acid [8]. Rop et al., measured flavonoid content among nine different cultivars and reported "smoky" to have highest level (550.5 $\pm 20.5 \mathrm{mg}$ of rutin/kg FW) of flavonoid [9]. Further, a study by Wang and Mazza found that strong crude extract of juneberries has the ability to prevent the production of nitric oxide in LPS/IFN-gamma-activated RAW 264.7 macrophages [10]. Another study comparing two cultivars of juneberries discovered that "Thiessen" and "Smoky" has the highest radical scavenging activity due to the high concentration of anthocyanin [11]. As many studies have shown A. alnifolia to have antioxidant and chemopreventive effects, this study hypothesizes that the main chemical agents responsible for chemopreventive effect are phenolic compounds and investigates the total phenolic content, orthophenolic content, 2,2-diphenyl-1picrylhydrazyl (DPPH) radical scavenging antioxidant activity, 2,2'-azino-bis(3-ethylbenzothiazoline-6-sulphonic acid) (ABTS) radical scavenging activity, and cell based antioxidant activity of juneberry extracts for the purpose of discovering novel therapeutics.

\section{MATERIALS AND METHODS}

\section{Plant Material}

The frozen berries of Amelanchier alnifolia grown commercially and in the wild were provided from cultivars near Fort Berthold Community College, North Dakota. All samples were chosen by Prof. K Hartman, Chair Science Department, Fort-Berthold Community College, North Dakota. The frozen berries were stored at $-20{ }^{\circ} \mathrm{C}$ prior to investigation.

\section{Preparation of Plant Extracts}

Frozen material $(1 \mathrm{~g})$ was weighed and $10 \mathrm{~mL}$ of $95 \%$ ethanol was used to homogenize using IKA (Wilmington, NC) homogenizer at 14,000 rpm for $5 \mathrm{~min}$. The sample test tube was rinsed with $4 \mathrm{~mL}$ of ethanol and centrifuged for 20 min at 4,000 rpm. Supernatant was diluted to $20 \mathrm{~mL}$ with $95 \%$ ethanol, sealed and stored in the refrigerator until use. This method is thought to extract free phenolics, bound phenolics and soluble-conjugated phenolics.

\section{Cell-free Antioxidant Chemical Assays}

Total Phenolic content Assay: A 35\% sodium carbonate solution was prepared. $50 \mu \mathrm{L}$ of Folin Ciocalteu's phenol reagent, $50 \mu \mathrm{L}$ of the sample extract, $300 \mu \mathrm{L}$ of the sodium carbonate solution, and $3.5 \mathrm{~mL}$ of deionized water was added to each cuvette. The reaction mixture in the cuvette was left to sit for $15 \mathrm{~min}$ before analysis. Samples were analysis at $730 \mathrm{~nm}$ on SpectroVis Plus (Vernier) spectrophotometer, using five extracts from each sample set. A blank sample was used for the calibration of the instrument. The samples were measured against a standard curve using tannic acid (Alfa Aesar, 93\%) as the sample extract, in concentrations of 0.2, 0.4, 0.6, 0.8, and 1.0 mg/mL (Fig. S1A).

Antioxidant Activity Assay: A DPPH solution of $100 \mu \mathrm{M}$ was prepared by dissolving $32 \mathrm{mg}$ of DPPH into $800 \mathrm{~mL}$ of $95 \%$ ethanol. A $500 \mu \mathrm{L}$ volume of the sample extract was mixed with $3.0 \mathrm{~mL}$ of the DPPH solution in a cuvette. The reaction mixture was allowed to sit for $10 \mathrm{~min}$. The samples were analyzed on a Shimadzu spectrophotometer at $517 \mathrm{~nm}$ in triplicates. A control solution was prepared by adding $500 \mu \mathrm{L}$ of $95 \%$ ethanol to a cuvette with $3.0 \mathrm{~mL}$ of the DPPH solution, and $95 \%$ ethanol was used as a blank for calibration of the instrumentation. Antioxidant activity is measured using the following equation:

$$
\text { Antioxidant activity }(\%)=\frac{[A(\text { control })-A(\text { sample })]}{A(\text { control })} \times 100
$$

For a comparison, a $1.4 \mathrm{mg} / \mathrm{mL}$ quercetin dihydrate (Sigma Aldrich, 98\%) was used. 
Orthophenolic Content Assay: $1 \mathrm{~mL}$ aliquots of the sample extract were dried under force, re-dissolved into $1 \mathrm{~mL}$ of pure water and vortexed for ten seconds to facilitate the compound going into the solution. To this $1 \mathrm{~mL}$ solution, 1 $\mathrm{mL}$ of $0.1 \mathrm{M}$, pH 6.5 phosphate buffer and $2 \mathrm{~mL}$ of a $5 \%(\mathrm{v} / \mathrm{v})$ sodium molybdate solution were sequentially added, and the reaction mixture was left to sit for $15 \mathrm{~min}$ prior to analysis. Samples were analyzed using Molecular Devices SpectraMax spectrophotometer at $350 \mathrm{~nm}$. The sample extract was compared against a standard curve of Caffeic acid (Indofine, 97\%) in the range of $0-10 \mu \mathrm{g} / \mathrm{mL}$ (Fig. S1B).

ABTS Radical Cation Decolorization Assay: ABTS was dissolved in water to form a $7 \mathrm{mM}$ solution. ABTS radical cations were then produced by reacting ABTS stock solution with $2.45 \mathrm{mM}$ solution of potassium persulfate (final concentration). The mixture was allowed to stand in the dark at room temperature for $12-16 \mathrm{~h}$. The ABTS radical solution was adjusted with methanol to an absorbance of $0.700 \pm 0.020$ at $734 \mathrm{~nm}$. To $280 \mu \mathrm{L}$ of this solution of ABTS was added to $20 \mu \mathrm{L}$ of sample in a 96-well plate. The mixture was incubated for $5 \mathrm{~min}$ at $30^{\circ} \mathrm{C}$ and the absorbance at $734 \mathrm{~nm}$ was measured using a synergy H1 Biotek microplate reader and the inhibition percentage of the radical scavenging activity was then calculated. For a comparison, a $0.13 \mathrm{mg} / \mathrm{mL}$ Trolox (ACROS Organics, 97\%) was used.

\section{Cell-based Antioxidant Assay (Anti-TBHP)}

Cell Culture: Human hepatocellular liver carcinoma cell line hepG2 was used to test cytoprotective activity of juneberry extracts. These Cells were maintained as a monolayer culture grown in a $75 \mathrm{~cm}^{2}$ flask in an incubator in DMEM supplemented by $10 \%$ fetal bovine serum (FBS) and $1 \%$ antibiotic.

Bioassay Procedure: Cytoprotection assay was carried out according to Hamed et al. 2012. Plant extracts were evaporated by nitrogen gas and dissolved in DMSO for the cell assay. HepG2 cells were seeded into a 96 well plates $\left(10 \times 10^{4}\right.$ cells $\left./ \mathrm{mL}\right)$. Cells were grown until confluent monolayers were obtained. Cells were then pretreated with the $A$. alnifolia extracts $(100 \mu \mathrm{g}, 50 \mu \mathrm{g}, 25 \mu \mathrm{g}$ and $12.5 \mu \mathrm{g})$ and 5\% DMSO control for 20 hours. The medium was removed, cells were washed with $200 \mu \mathrm{L}$ of Dulbecco's modified phosphate buffered saline (DPBS) (200 $\mu \mathrm{L} /$ well). Media containing $500 \mu \mathrm{M}$ tertiary-butyl hydroperoxide (TBHP) (Acros, 70\%) with 2\% FBS final concentration was added to the cells and incubated for 5 hours. Following TBHP oxidative stress treatment, Cell viability was assessed using MTT assay. Reference compound, quercetin dihydrate (Sigma Aldrich, 98\%) was used parallel in this assay (Figs. S2-S8).

\section{RESULTS AND DISCUSSION}

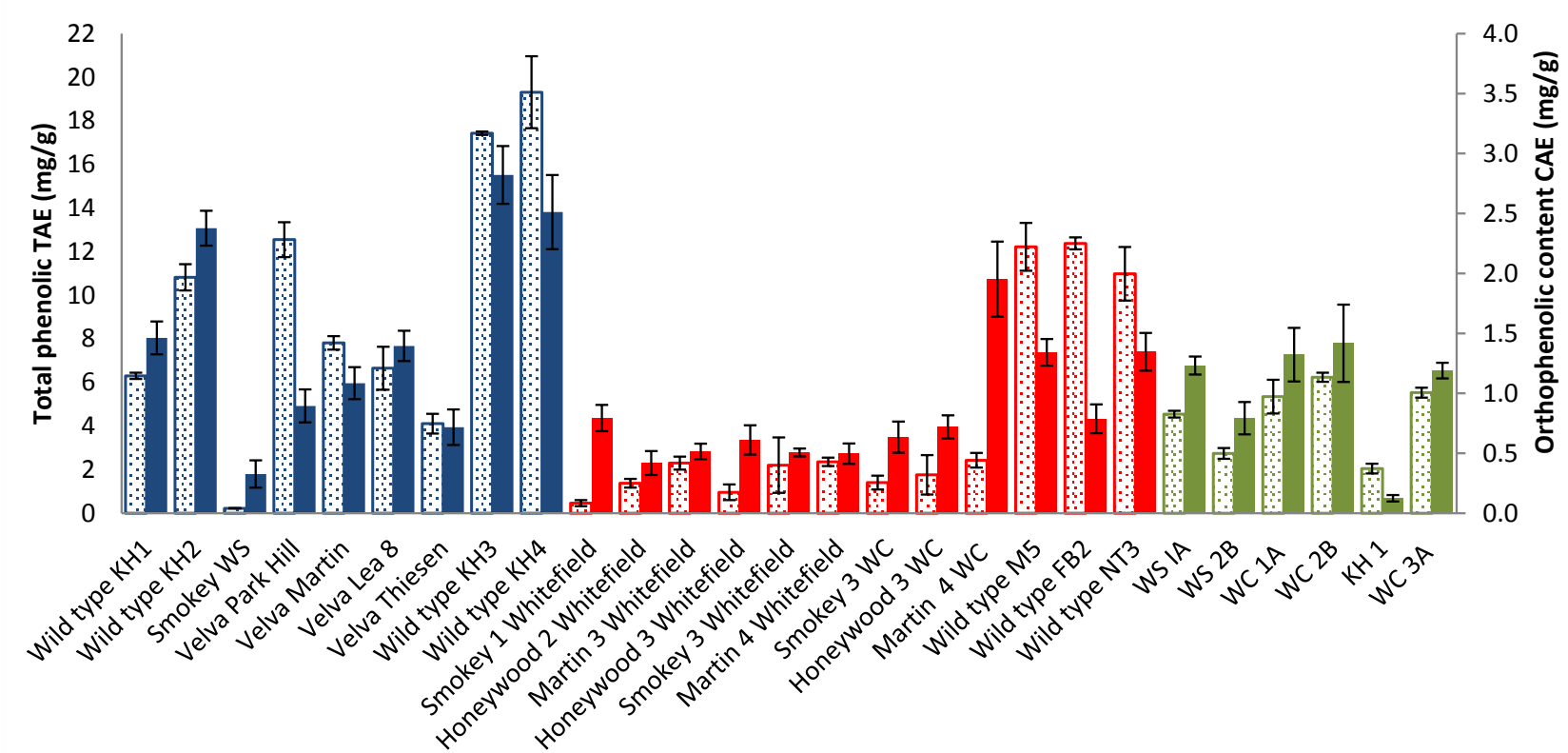

Fig. (1). Representative data showing the total phenolic content (solid) and Orthophenolic Content (pattern) in ethanol extracts of juneberries from cultivars in 2012 (blue), 2013 (red), and 2014 (green). Data shown are means \pm standard deviation ( $\mathrm{n}=5$ experiments). 
Table 1. Total phenolic content, DPPH antioxidant activity, ABTS radical inhibition and orthophenolic content in juneberries.

\begin{tabular}{|c|c|c|c|c|c|}
\hline Year & Sample Name & Total Phenolic (mg/g) & $\begin{array}{c}\text { DPPH Antioxidant Activity } \\
(\%)\end{array}$ & $\begin{array}{c}\text { ABTS radical Inhibition } \\
(\%)\end{array}$ & Orthophenolic content $(\mathrm{mg} / \mathrm{g})$ \\
\hline & Quercetin dihydrate & - & $86.20 \pm 0.05$ & - & - \\
\hline & Trolox & - & - & $94.03 \pm 0.21$ & - \\
\hline \multirow[t]{9}{*}{2012} & Wild type KH1 & $6.301 \pm 0.144$ & $92.79 \pm 1.49$ & $20.08 \pm 1.43$ & $1.46 \pm 0.14$ \\
\hline & Wild type $\mathrm{KH} 2$ & $10.822 \pm 0.603$ & $97.19 \pm 0.23$ & $29.90 \pm 1.54$ & $2.38 \pm 0.15$ \\
\hline & Smokey WS & $0.226 \pm 0.003$ & $68.48 \pm 1.46$ & $3.33 \pm 0.75$ & $0.33 \pm 0.11$ \\
\hline & Velva Park Hill & $12.552 \pm 0.800$ & $90.79 \pm 2.47$ & $10.09 \pm 1.13$ & $0.89 \pm 0.14$ \\
\hline & Velva Martin & $7.813 \pm 0.309$ & $87.80 \pm 2.42$ & $8.86 \pm 0.87$ & $1.08 \pm 0.13$ \\
\hline & Velva Lea 8 & $6.652 \pm 0.985$ & $96.45 \pm 0.54$ & $28.72 \pm 0.37$ & $1.40 \pm 0.13$ \\
\hline & Velva Thiesen & $4.107 \pm 0.452$ & $93.39 \pm 1.38$ & $7.86 \pm 0.41$ & $0.72 \pm 0.15$ \\
\hline & Wild type KH3 & $17.429 \pm 0.076$ & $93.64 \pm 0.97$ & $60.25 \pm 1.65$ & $2.82 \pm 0.24$ \\
\hline & Wild type KH4 & $19.311 \pm 1.651$ & $93.09 \pm 1.05$ & $58.82 \pm 0.48$ & $2.51 \pm 0.31$ \\
\hline \multirow[t]{12}{*}{2013} & Smokey 1 Whitefield & $0.461 \pm 0.137$ & $58.78 \pm 1.37$ & $1.81 \pm 0.51$ & $0.79 \pm 0.11$ \\
\hline & Honeywood 2 Whitefield & $1.374 \pm 0.198$ & $85.01 \pm 1.94$ & $15.65 \pm 0.65$ & $0.42 \pm 0.10$ \\
\hline & Martin 3 Whitefield & $2.300 \pm 0.299$ & $81.66 \pm 2.33$ & $13.28 \pm 1.41$ & $0.52 \pm 0.06$ \\
\hline & Honeywood 3 Whitefield & $0.959 \pm 0.358$ & $79.25 \pm 2.09$ & $11.05 \pm 1.23$ & $0.61 \pm 0.12$ \\
\hline & Smokey 3 Whitefield & $2.205 \pm 1.275$ & $69.01 \pm 2.81$ & $1.60 \pm 0.55$ & $0.51 \pm 0.03$ \\
\hline & Martin 4 Whitefield & $2.356 \pm 0.194$ & $74.78 \pm 1.89$ & $6.26 \pm 0.67$ & $0.50 \pm 0.08$ \\
\hline & Smokey 3 WC & $1.407 \pm 0.317$ & $86.88 \pm 1.62$ & $8.25 \pm 0.62$ & $0.63 \pm 0.13$ \\
\hline & Honeywood $3 \mathrm{WC}$ & $1.762 \pm 0.906$ & $82.69 \pm 0.30$ & $10.21 \pm 0.62$ & $0.72 \pm 0.10$ \\
\hline & Martin $4 \mathrm{WC}$ & $2.428 \pm 0.337$ & $91.16 \pm 2.84$ & $14.32 \pm 0.93$ & $1.95 \pm 0.31$ \\
\hline & Wild type M5 & $12.220 \pm 1.101$ & $97.81 \pm 0.37$ & $42.89 \pm 6.39$ & $1.34 \pm 0.11$ \\
\hline & Wild type FB2 & $12.379 \pm 0.277$ & $97.91 \pm 0.40$ & $44.85 \pm 3.81$ & $0.79 \pm 0.12$ \\
\hline & Wild type NT3 & $10.984 \pm 1.231$ & $97.54 \pm 0.57$ & $34.63 \pm 1.33$ & $1.35 \pm 0.16$ \\
\hline \multirow[t]{6}{*}{2014} & WS 1A & $4.546 \pm 0.156$ & $92.95 \pm 1.60$ & $20.71 \pm 0.33$ & $1.23 \pm 0.07$ \\
\hline & WS 2B & $2.745 \pm 0.248$ & $69.34 \pm 1.69$ & $6.97 \pm 0.58$ & $0.79 \pm 0.14$ \\
\hline & WC 1A & $5.347 \pm 0.773$ & $98.60 \pm 1.12$ & $20.51 \pm 1.86$ & $1.32 \pm 0.22$ \\
\hline & WC 2B & $6.234 \pm 0.209$ & $97.28 \pm 0.79$ & $19.62 \pm 0.76$ & $1.42 \pm 0.32$ \\
\hline & \begin{tabular}{|l|}
$\mathrm{KH}$ \\
\end{tabular} & $2.046 \pm 0.227$ & $50.08 \pm 0.77$ & $1.90 \pm 0.11$ & $0.12 \pm 0.03$ \\
\hline & WC 3A & $5.530 \pm 0.225$ & $96.95 \pm 0.98$ & $18.64 \pm 0.36$ & $1.19 \pm 0.07$ \\
\hline
\end{tabular}

Table 2. Integration of samples that showed significant cytoprotection together with the respective TPC, antioxidant activity, ABTS radical inhibition and orthophenolic content.

\begin{tabular}{|c|c|c|c|c|c|}
\hline Name & $\begin{array}{c}\text { Cytoprotection } \\
\text { At } 100 \text { ug juneberry } \\
\text { concentration }(\%)\end{array}$ & $\begin{array}{l}\text { Total Phenolic } \\
\text { content (mg/g) }\end{array}$ & $\begin{array}{c}\text { DPPH Antioxidant } \\
\text { Activity (\%) }\end{array}$ & $\begin{array}{c}\text { ABTS radical } \\
\text { Inhibition (\%) }\end{array}$ & $\begin{array}{c}\text { Orthophenolic content } \\
(\mathrm{mg} / \mathrm{g})\end{array}$ \\
\hline Velva Martin & 48 & $7.813 \pm 0.309$ & $87.80 \pm 2.42$ & $8.86 \pm 0.87$ & $1.08 \pm 0.13$ \\
\hline Wild type KH4 & 46 & $19.311 \pm 1.651$ & $93.09 \pm 1.05$ & $58.82 \pm 0.48$ & $2.51 \pm 0.31$ \\
\hline Wild type NT3 & 42 & $10.984 \pm 1.232$ & $97.54 \pm 0.57$ & $34.63 \pm 1.33$ & $1.35 \pm 0.16$ \\
\hline WC 3A & 55 & $5.530 \pm 0.225$ & $96.95 \pm 0.98$ & $18.64 \pm 0.36$ & $1.19 \pm 0.07$ \\
\hline WC 2B & 56 & $6.234 \pm 0.209$ & $97.28 \pm 0.79$ & $19.62 \pm 0.76$ & $1.42 \pm 0.32$ \\
\hline
\end{tabular}




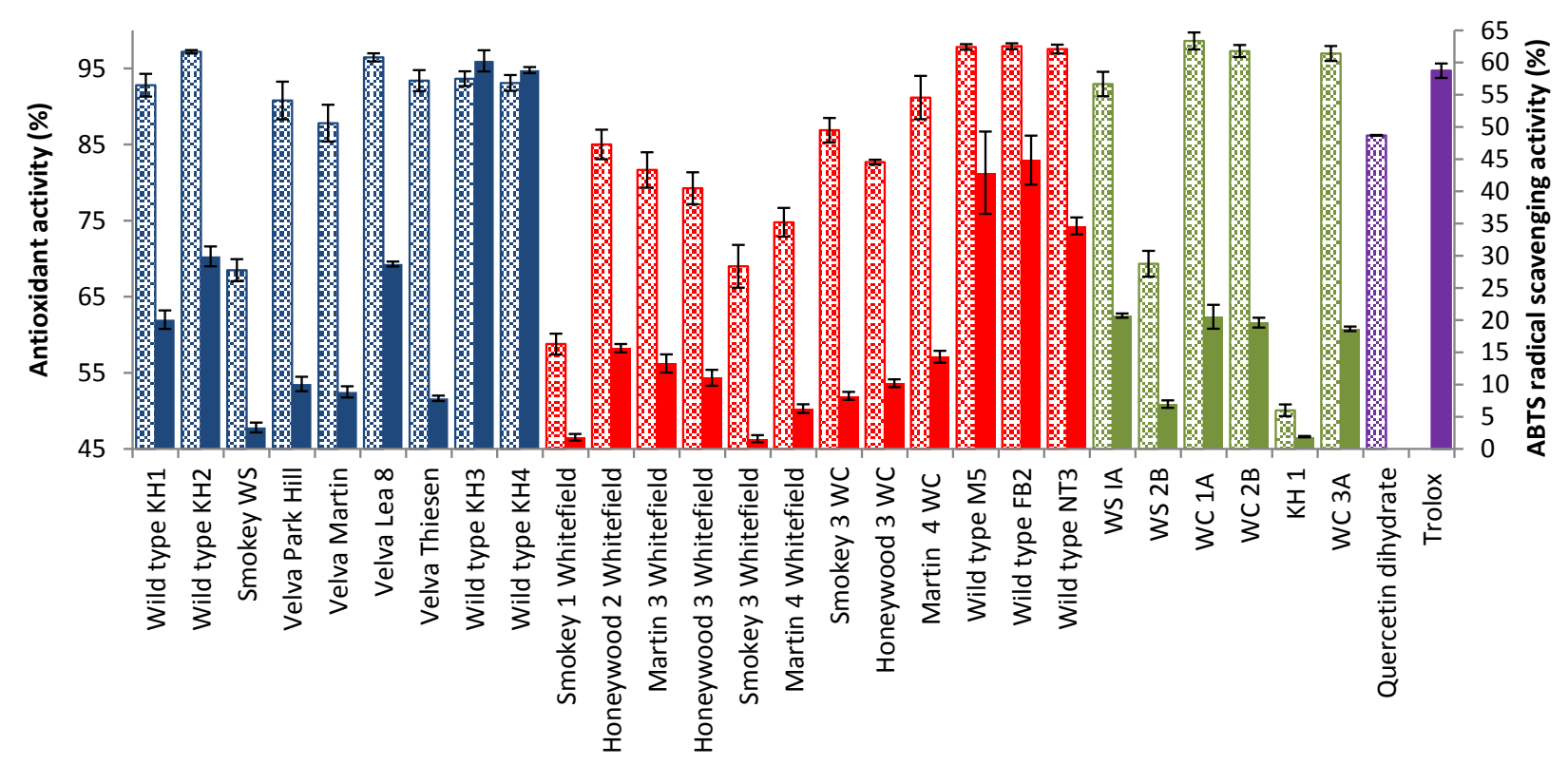

Fig. (2). Representative data showing DPPH radical scavenging antioxidant activity (pattern) and ABTS radical inhibition percentage (solid) by ethanol extracts of juneberries in 2012(blue), 2013(red) and 2014(green). Data shown are means \pm standard deviation ( $\mathrm{n}=5$ experiments). For comparison, positive controls (purple) quercetin dihydrate (pattern) for the antioxidant activity assay and Trolox (solid) for the ABTS radical inhibition assay are displayed in this plot.

\section{Total Phenolic Contents}

Total phenolic content (tannic acid equivalents, TAE) in juneberries (Fig. 1) ranged from $0.2261 \pm 0.0031$ to 19.311 $\pm 1.651 \mathrm{mg} / \mathrm{g}$ of frozen weight (FW). Data are in accordance with previous studies of Saskatoon berries where TPC was found to be 2.52 to $3.82 \mathrm{~g}$ gallic acid $\mathrm{Eq} \cdot \mathrm{kg}^{-1}$ of $\mathrm{FW}$ [12]. Total phenolic content determined in this study is higher than the reported values in Rop et al. However, it must be noted that we used tannic acid as our standard for the assay.Using a similar expression, Fredes, Carolina, et al (2014) observed a TPC, $14.6 \mathrm{~g} \mathrm{GE} \mathrm{kg}^{-1} \mathrm{FW}$ of maqui berry, $3.9 \mathrm{~g} \mathrm{GE} \mathrm{kg} 1$ FW of pomegranate, and $3.0 \mathrm{~g} \mathrm{GE} \mathrm{kg-1} \mathrm{FW} \mathrm{of} \mathrm{raspberry} \mathrm{[13].} \mathrm{It} \mathrm{is} \mathrm{clear} \mathrm{that} \mathrm{TPC} \mathrm{determined} \mathrm{in} \mathrm{juneberries} \mathrm{are} \mathrm{higher}$ than in most other fruits and therefore is a great source of dietary antioxidants. Significant difference can be seen in TPC between juneberries of the same year and different years' crops. Phenolic content in fruits has been shown to be influenced by cultivar, abiotic stresses such as harvest year, water availability in soil and temperatures [14, 15]. Wild type (juneberries grown in the wild) such as KH2,KH3, KH4 of 2012 and M5, NT3 and FB2 of 2013 showed higher total phenolic content than domestic cultivars, with Velva Park Hill and Velva martin being the exceptions. Which implies that the natural growth conditions are better suited for encouraging production of secondary metabolites beneficial for human health. Overall, juneberries of 2012 showed much higher TPC than other years, environmental factors are however unknown (Figs. S9-S11).

\section{Antioxidant Activity}

DPPH assay is the most renowned and widely used assay as there is no other simpler or cheaper antioxidant assay in use. This method of stable DPPH free radical scavenging is used to assess the antioxidant activity of compounds or extracts in a less time consuming manner [16]. Antioxidant activity of juneberries (Table 1) (Fig. 2) ranged from 50.08 \pm 0.77 to $98.60 \pm 1.12 \%$ overall. Flavonoids are strong antioxidants against free radicals, as they are efficient "radicalscavengers". This scavenging activity is due to the phenol functional group that acts as a source of hydrogen atoms, such that when radicals are produced, electrons can be delocalize over the flavonoid structure [17]. From Fig. (2) demonstrates that majority of the juneberry samples showed a higher antioxidant activity than the reference compound quercetin dihydrate $(86.20 \pm 0.05 \%)$. A similar study by Poina et al, investigated the antioxidant activity of cherry, strawberry, bilberry, red gooseberry, raspberry and blackberry and discovered that bilberry showed the highest antioxidant activity of 40.60\% [18]. Juneberries from ND cultivars show higher scavenging activity than bilberry extracts used in the study. Highest antioxidant activity reported in the study of 2012, KH1, KH2, Velva Park Hill, Velva Lea 8, Velva Thiesen, KH3, KH4,; 2013, M5, FB2,NT3 and 2014; WC1A, WC2B, WC3A. Juxtaposing total phenols 
and antioxidant activity results from our studies, a significant correlation can be seen Figs. (S12-S14). This implies that the antioxidant activity seen is possibly due to the high levels of phenolic content in juneberries.

Orthophenolic Content Previous work conducted by Torres et al shows that orthophenolic compounds are better antioxidants in comparison to other phenol constituents [19]. Additionally, a study conducted on antitumor activity showed a positive correlation with the orthophenolic content in wheat samples given to Min mice [20]. As a result we investigated the orthophenolic content in juneberries to test for any correlation with the other assays. Orthophenolic content was recorded in Caffeic Acid Equivalents (CAE), mg. $\mathrm{g}^{-1}$ of FW. Orthophenolic content in juneberries ranged from $0.12 \pm 0.03$ to $2.38 \pm 0.15 \mathrm{mg}^{-1}{ }^{-1}$ of FW (Fig. 1). Overall highest orthophenolic content was shown in 2012 juneberries; KH2, KH3, and KH4. 2013 juneberry crops show a moderate level of orthophenolic content with the highest amount in Martin 4 WC and lesser amounts in M5 and NT3. In 2014, WC1A, WC2B, and WC3A cultivars showed the highest orthophenolic content. Comparing results across the three years, a decline of orthophenolic content in juneberries can be observed. A notable correlation also exists between CAE levels and antioxidant activity in this study (Figs. S15-S17).

\section{ABTS Radical Cation Decolorization Assay}

The ABTS radical cation decolorization assay present the free radical scavenging response to ABTS of Juneberry extracts (Tables 1 and 2). Highest ABTS inhibition by juneberries of 2012 was seen by KH3and KH4, while M5, FB2 and NT3 had the highest inhibition in 2013. 2014 Juneberry samples showed much lower ABTS inhibition percentages with the highest by WS 1A and WC 1A. In comparison to the positive control, Trolox which displayed an inhibition of $94.03 \pm 0.21 \%$, juneberries from wild type KH3 displayed an inhibition of $60.25 \pm 1.65 \%$. ABTS inhibition data correlates closely with finding of TPC, antioxidant activity, ABTS radical inhibition, and orthophenolic content. This suggests that phenolic content of juneberries plays an important role in inhibitory activity and in overall antioxidant activity. Many other studies as well assert that polyphenols highly correlate with the antioxidant activity in fruits [21, $22]$.

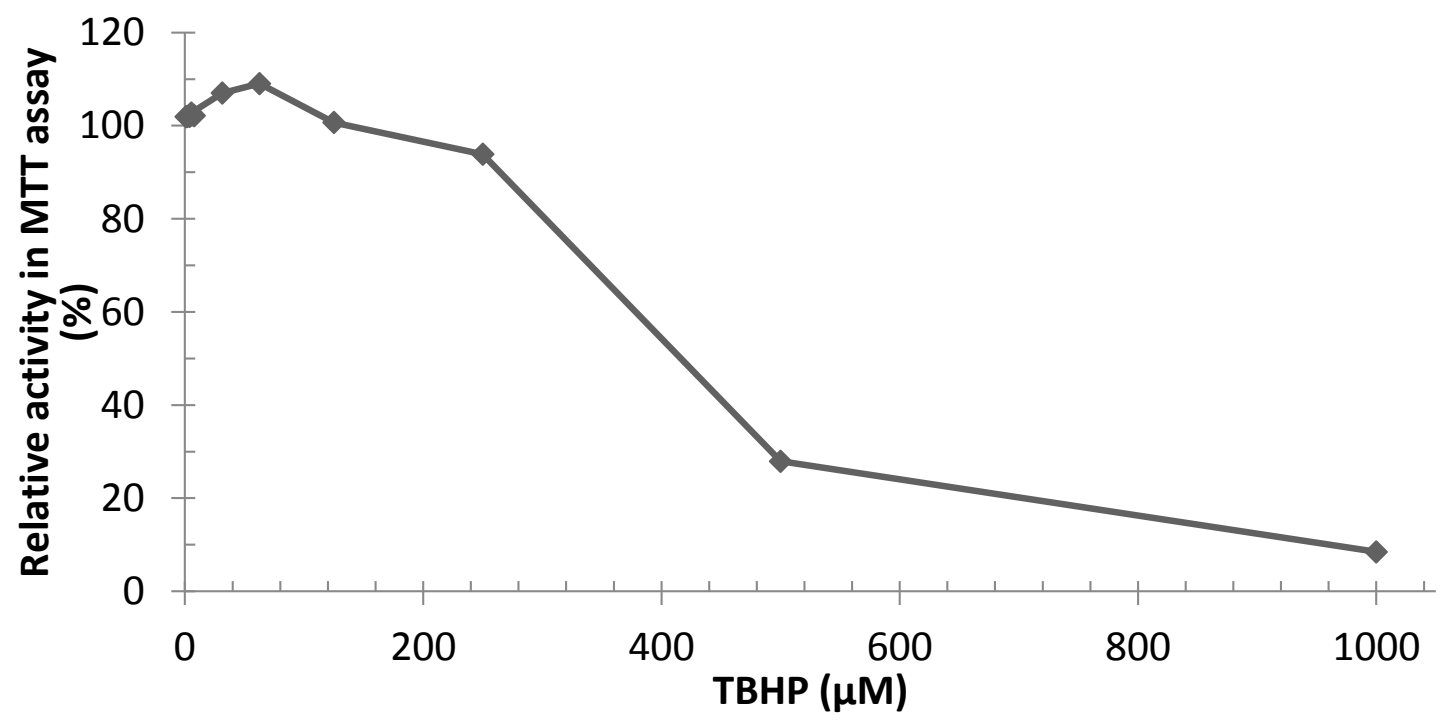

Fig. (3). Cytotoxicity of TBHP in HepG2 cells.

\section{Cell-based Antioxidant Assay}

Cytotoxicity assay was carried out on TBHP concentrations ranging from $1000 \mathrm{uM}$ to 0.9 uM on HepG2 cells. While $400 \mathrm{uM}$ showed $50 \%$ cell survival this was not sufficient of a concentration to kill cells in the cytoprotection assay. Therefore, a concentration of $500 \mathrm{uM}$ was used, as shown in Fig. (3) this produced a 38\% cell survival. The pretreatment of hepG2 cells with $100 \mu \mathrm{g} / \mu \mathrm{L}$ of 2014 sample WC $2 \mathrm{~B}$ produced a $56 \%$ viability. Quercetin dihydrate control showed $90 \%$ cytoprotection under the same treatment. Five samples with the highest cytoprotection activity is shown in Table 2. along with its data for total phenol, antioxidant activity, ABTS radical scavenging activity and 
orthophenolic content. Cell-based antioxidant activity showed very high correlation with DPPH radical scavenging activity. A similar study conducted on HeLa cancer cells using various berry extracts show a wide range of cytoprotection of $20 \%-98 \%$ [23]. Therefore, our findings on the cytoprotection by juneberry extracts in HepG2 cells are well within this range.

\section{CONCLUSION}

Wild type KH4 and KH3 of 2012 juneberry crop show higher phenolic content, orthophenolic content, DPPH radical scavenging, ABTS radical inhibition, and few of the highest cell based cytoprotection. Our data suggest that juneberries grown in the wild as opposed to those grown in cultivars are richer in bioactive secondary metabolites. This idea is in accordance with similar studies conducted on various other berries reporting a higher levels of bioactive phytochemicals and total phenols in organically bred fruits than their commercially grown counterparts [15, 24]. Berries grown in the wild have a myriad of positive health benefits and are ideal to study secondary phytochemicals released in response to natural chemical and physical stresses [25]. However, greater knowledge in the environmental conditions, soil quality, and seasonal variations would be beneficial to produce juneberries with higher nutritional value. Additionally our results show that total phenolic content and orthophenolic content in juneberries from 2012 were higher than in juneberries obtained from the 2013 and 2014. Food nutritionists investigating fruits and vegetables grown today and those grown seven decades back have shown a lower amount of calcium, iron, vitamin $\mathrm{C}$ and phytochemicals have been quantified in current domesticated crops [25].Therefore, even among wild juneberries it is possible that the nutrient content may decline over time corresponding to the changes in the environment. The high phytochemical content and bioactivity shown by $A$. alnifolia in this study indicates that juneberries have great therapeutic benefit and is also an excellent source of dietary antioxidants. However, due to the variations in phenolic content in different cultivars and breeding practices, the sources of the juneberries should be carefully assessed when recommended for their positive health benefits.

\section{LIST OF ABBREVIATIONS}

$\begin{array}{lll}\text { ABTS } & = & 2,2 \text {-azino-bis(3-ethylbenzothiazoline-6-sulphonic acid) } \\ \text { DMEM } & = & \text { Dulbecco's modified eagle medium } \\ \text { DPPH } & = & \text { Foetal bovine serum } \\ \text { FBS } & = & \text { Frozen weight } \\ \text { FW } & = & \text { (3-(4,5-Dimethylthiazol-2-yl)-2,5-Diphenyltetrazolium Bromide) } \\ \text { MTT } & = & \text { Reactive oxygen species } \\ \text { ROS } & = & \text { Teactive nitrogen species } \\ \text { RNS } & = & \text { Tertiary-Butyl hydroperoxide } \\ \text { TAE } & = & \text { Total phenolic content } \\ \text { TBHP } & = & 6 \text {-hydroxy-2, 5, 7, 8-tetramethylchroman-2-carboxylic acid } \\ \text { TPC } & \text { Trolox } & \end{array}$

\section{SUPPLEMENTARY MATERIAL}

Supplementary material is available on the publishers web site along with the published article.

\section{CONFLICT OF INTEREST}

The authors confirm that this article content has no conflict of interest.

\section{ACKNOWLEDGEMENTS}

The authors acknowledge the USDA-NIFA (Award \# 2011-38424-30653) for the financial support and Fort Bertholdt Community College, North Dakota for all the support in making this project a success. 


\section{REFERENCES}

[1] Ames, B.N.; Shigenaga, M.K.; Hagen, T.M. Oxidants, antioxidants, and the degenerative diseases of aging. Proc. Natl. Acad. Sci. USA, 1993, 90(17), 7915-7922.

[http://dx.doi.org/10.1073/pnas.90.17.7915] [PMID: 8367443]

[2] Huang, D.; Ou, B.; Prior, R.L. The chemistry behind antioxidant capacity assays. J. Agric. Food Chem., 2005, 53(6), 1841-1856. [http://dx.doi.org/10.1021/jf030723c] [PMID: 15769103]

[3] Geybels, M.S.; Verhage, B.A.; Arts, I.C.; van Schooten, F.J.; Goldbohm, R.A.; van den Brandt, P.A. Dietary flavonoid intake, black tea consumption, and risk of overall and advanced stage prostate cancer. Am. J. Epidemiol., 2013, 177(12), 1388-1398. [http://dx.doi.org/10.1093/aje/kws419] [PMID: 23722011]

[4] Hertog, M.G.; Feskens, E.J.; Hollman, P.C.; Katan, M.B.; Kromhout, D. Dietary antioxidant flavonoids and risk of coronary heart disease: the Zutphen Elderly Study. Lancet, 1993, 342(8878), 1007-1011. [http://dx.doi.org/10.1016/0140-6736(93)92876-U] [PMID: 8105262]

[5] Vinod, B.S.; Maliekal, T.T.; Anto, R.J. Phytochemicals as chemosensitizers: from molecular mechanism to clinical significance. Antioxid. Redox Signal., 2013, 18(11), 1307-1348. [http://dx.doi.org/10.1089/ars.2012.4573] [PMID: 22871022]

[6] Rice-Evans, C.A.; Miller, N.; Paganga, G. Trends in plant science; Elsevier Science: Kidlington, Oxford, 1997, pp. 152-159.

[7] Nesom, G. 2006. Available from: http://plants.usda.gov/core/profile?symbol=amal2.

[8] Lavola, A.; Karjalainen, R.; Julkunen-Tiitto, R. Bioactive polyphenols in leaves, stems, and berries of Saskatoon (Amelanchier alnifolia Nutt.) cultivars. J. Agric. Food Chem., 2012, 60(4), 1020-1027. [http://dx.doi.org/10.1021/jf204056s] [PMID: 22220589]

[9] Rop, O.; Reznicek, V.; Mlcek, J.; Jurikova, T.; Sochor, J.; Kizek, R.; Humpolicek, P.; Balik, J. Nutritional values of new Czech cultivars of Saskatoon berries (Amelanchier alnifolia Nutt.). Hort. Sci., 2012, 39, 123-128.

[10] Wang, J.; Mazza, G. Inhibitory effects of anthocyanins and other phenolic compounds on nitric oxide production in LPS/IFN-gammaactivated RAW 264.7 macrophages. J. Agric. Food Chem., 2002, 50(4), 850-857.

[http://dx.doi.org/10.1021/jf010976a] [PMID: 11829656]

[11] Hu, C.; Kwok, B.H.; Kitts, D.D. Saskatoon berries (Amelanchier alnifolia Nutt.) scavenge free radicals and inhibit intracellular oxidation. Food Res. Int., 2005, 38, 1079-1085. [http://dx.doi.org/10.1016/j.foodres.2005.02.024]

[12] Rop, O.; Mlcek, J.; Jurikova, T.; Sochor, J. Kizek. Antioxidant properties of saskatoon berry (Amelanchier alnifolia Nutt.) fruits. Fruits, 2013, $68,435-444$. [http://dx.doi.org/10.1051/fruits/2013087]

[13] Fredes, C.; Montenegro, G.; Zoffoli, J.P.; Santander, F.; Robert, P. Comparison of the total phenolic content, total anthocyanin content and antioxidant activity of polyphenol-rich fruits grown in Chile. Cien. Inv. Agr., 2014, 41(1), 49-60. [http://dx.doi.org/10.4067/S0718-16202014000100005]

[14] Wang, S.Y.; Lin, H.S. Antioxidant activity in fruits and leaves of blackberry, raspberry, and strawberry varies with cultivar and developmental stage. J. Agric. Food Chem., 2000, 48(2), 140-146. [http://dx.doi.org/10.1021/jf9908345] [PMID: 10691606]

[15] Wang, S.Y.; Chen, C.T.; Sciarappa, W.; Wang, C.Y.; Camp, M.J. Fruit quality, antioxidant capacity, and flavonoid content of organically and conventionally grown blueberries. J. Agric. Food Chem., 2008, 56(14), 5788-5794. [http://dx.doi.org/10.1021/jf703775r] [PMID: 18590274]

[16] Brand-Williams, W.; Cuvelier, M.E.; Berset, C. Use of a free radical method to evaluate antioxidant activity. LWT-. Food Sci. Technol. (Campinas.), 1995, 28, 25-30.

[17] Di Majo, D.; Giammanco, M.; La Guardia, M.; Tripoli, E.; Giammanco, S.; Finotti, E. Flavanones in citrus fruit: Structure-antioxidant activity relationships. J. Res. Intl., 2005, 38, 1161-1166.

[18] Poiană, M.; Bragea, M.; Moigrădean, D.; Stoin, D.; Gergen, I. Evaluation of antioxidant properties and color structure for some natural concentrates from berries and garden fruits. Bull. UASVM, Agric., 2008, 65(2), 351-356.

[19] Torres de Pinedo, A.; Penalver, P.; Morales, J.C. Synthesis and evaluation of new phenolic-based antioxidants: Structure-activity relationship. Food Chem., 2007, 103, 55-61. [http://dx.doi.org/10.1016/j.foodchem.2006.07.026]

[20] Drankhan, K.; Carter, J.; Madl, R.; Klopfenstein, C.; Padula, F.; Lu, Y.; Warren, T.; Schmitz, N.; Takemoto, D.J. Antitumor activity of wheats with high orthophenolic content. Nutr. Cancer, 2003, 47(2), 188-194. [http://dx.doi.org/10.1207/s15327914nc4702_12] [PMID: 15087272]

[21] Moyer, R.A.; Hummer, K.E.; Finn, C.E.; Frei, B.; Wrolstad, R.E. Anthocyanins, phenolics, and antioxidant capacity in diverse small fruits: vaccinium, rubus, and ribes. J. Agric. Food Chem., 2002, 50(3), 519-525. [http://dx.doi.org/10.1021/jf011062r] [PMID: 11804523] 
[22] Vasantha Rupasinghe, H.P.; Jayasankar, S.; Lay, W. Variation in total phenolic and antioxidant capacity among European plum genotypes. Sci. Hortic. (Amsterdam), 2006, 108, 243-246.

[http://dx.doi.org/10.1016/j.scienta.2006.01.020]

[23] Battino, M.; Beekwilder, j; Denoyes-Rothan, B.; Laimer, M.; McDougall, G.J.; Mezzetti, B. Bioactive compounds in berries relevant to human health. Nutr. Rev., 2009, 67, 145-150. [http://dx.doi.org/10.1111/j.1753-4887.2009.00178.x]

[24] Mikulic-Petkovsek, M.; Schmitzer, V.; Slatnar, A.; Stampar, F.; Veberic, R. Composition of sugars, organic acids, and total phenolics in 25 wild or cultivated berry species. J. Food Sci., 2012, 77(10), C1064-C1070. [http://dx.doi.org/10.1111/j.1750-3841.2012.02896.x] [PMID: 22924969]

[25] Ann Lila, M. The nature-versus-nurture debate on bioactive phytochemicals: the genome versus terroir. J. Sci. Food Agric., 2006, 86(15), 2510-2515.

[http://dx.doi.org/10.1002/jsfa.2677]

(C) Gunawardana et al. ; Licensee Bentham Open

This is an open access article licensed under the terms of the Creative Commons Attribution-Non-Commercial 4.0 International Public License (CC BY-NC 4.0) (https://creativecommons.org/licenses/by-nc/4.0/legalcode), which permits unrestricted, non-commercial use, distribution and reproduction in any medium, provided the work is properly cited. 